\title{
A Review on Some Natural Biopolymers and Their Applications in Angiogenesis and Tissue Engineering
}

\author{
Hamed Nosrati ${ }^{1}$, Samiramis Pourmotabed ${ }^{2}$, Esmaeel Sharifi ${ }^{3,4,5 *}$ \\ ${ }^{1}$ Department of Tissue Engineering, Faculty of Advanced Technologies, Shahrekord University of Medical Sciences, Shahrekord, Iran \\ ${ }^{2}$ Department of Emergency Medicine, School of Medicine, Hamadan University of Medical Sciences, Hamadan, Iran \\ ${ }^{3}$ Department of Molecular Medicine and Genetics, School of Medicine, Hamadan University of Medical Sciences, Hamadan, Iran. \\ ${ }^{4}$ Research Center for Molecular Medicine, Hamadan University of Medical Sciences, Hamadan, Iran. \\ ${ }^{5}$ Department of Tissue Engineering and Biomaterials, School of Advanced Medical Sciences and Technologies, Hamadan University \\ of Medical Sciences, Hamadan, Iran
}

Corresponding Author: Esmaeel Sharifi, Assistant Professor, Department of Tissue Engineering and Biomaterials, School of Advanced Medical Sciences and Technologies, Hamadan University of Medical Sciences, Hamadan, Iran. Tel: +98-9131802807, Email: e.sharifi@umsha.ac.ir

Received July 2, 2018; Accepted July 28, 2018; Online Published September 30, 2018

\begin{abstract}
One of the concerning challenges for engineering and regenerating tissues is providing a suitable condition for development of a utilitarian vascular matrix. Natural polymers such as collagen, gelatin, chitosan, silk fibroin and fibrin are used as bio-compatible scaffolds to prepare appropriate biological and mechanical conditions for regenerative medicine and tissue engineering approaches. A wide range of studies demonstrated that using these biomaterials as scaffolds or engineered constructions such as hydrogels can provide a microenvironment to improve regeneration and repair of target tissues and organs through enhancing angiogenesis. They can be used single or in composition with each other. This review focused on some different natural polymeric constructs that have been incorporated in tissue engineering. Keywords: Tissue Engineering, Natural Polymers, Angiogenesis

Citation: Mo. A review on some natural biopolymers and their applications in angiogenesis and tissue engineering. J Appl Biotechnol Rep. 2018;5(3):81-91. doi:10.29252/jabr.05.03.01.
\end{abstract}

\section{Introduction}

Tissue engineering is a reparative means which merges biomaterials, cells and functional environmental factors to induce growth, proliferation and differentiation signals for promotion of tissue repair or functional regeneration. ${ }^{1,2}$ This interdisciplinary field faces many limitations which some of them are listed here ${ }^{3-5}$ :

- Proper selection of bio-compatible and bio-active materials for the purpose of repairing or regenerating the target tissue;

- Optimizing mechanical properties to produce a welldeveloped scaffold suitable for soft or under load tissues;

- The technique used to construct the appropriate engineered scaffold or structure;

- Identification of angiogenic factors in each tissue;

- Utilizing factors that can stimulate the production and secretion of angiogenic factors in target tissue; and

- How to transfer these factors to the tissue in absence of the native factors.

Natural polymers are biologically suitable materials to use as structures in tissue engineering applications (Figure 1). ${ }^{6}$ In this study, we focused on some polymers that used in research works in angiogenesis and other tissue engineering applications in different tissues and organs. The studied polymers are collagen, gelatin, chitosan, silk fibroin and fibrin. The aforementioned polymers have the ability of mimicking many properties of the extracellular matrix (ECM). Therefore, they can potentially induce the attachment, growth, migration, organization and differentiation of cells during regeneration of tissue or wound healing. ${ }^{7,8}$

The biological process that pre-existing vessels form new ones is called angiogenesis. As mentioned, angiogenesis is one of the most important issues in regeneration of a tissue. ${ }^{9}$ Vessels deliver nutrients and take away wastes and their lack is one of the problems for scaffolds or engineered constructions implanted in body. ${ }^{10}$ One of the current purposes in tissue engineering is to solve this concern by utilizing biomaterials that can act as a suitable environment to provide a condition for enhancing angiogenesis during tissue regeneration. These materials have also the potential of homing and releasing other angiogenic factors or effective elements while used as engineered constructs. Induction of endothelial cell homing, stimulation and activation of pro-angiogenic factors such as osteopontin, Forkhead box protein C2 (FOXC2), basic

Copyright $(0) 2018$ The Author(s). This is an open-access article distributed under the terms of the Creative Commons Attribution License (http:// creativecommons.org/licenses/by/4.0), which permits unrestricted use, distribution, and reproduction in any medium, provided the original work is properly cited. 
a. Injured bone

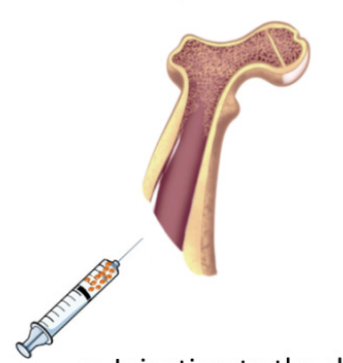

e. Injection to the defect

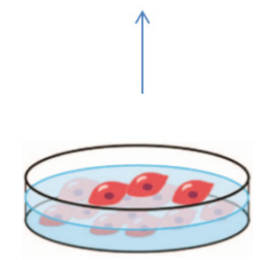

d. 3D Cell culture in injectable hydrogel b. Stem cell isolation

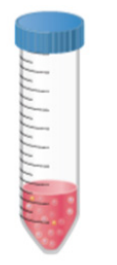

c. 2D Cell culture

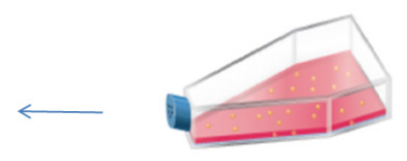

Figure 1. Using Natural Polymers as Hydrogel in Bone Tissue Engineering.

fibroblast growth factor (bFGF), Tumor necrosis factor alpha (TNF- $\alpha$ ), interleukin-1 (IL-1) and vascular endothelial growth factor (VEGF), inducing proliferation and migration of endothelial cells, improving the mitogenic response to angiogenic factors and overexpression of angiogenic genes are the effects of elements such as silicon, phosphorus, copper, magnesium and europium used in natural-based constructs to improve angiogenesis in tissue engineering approaches. ${ }^{1}$ In the following part, some natural polymers and their applications will be reviewed.

\section{Collagen}

Collagen is an essential protein of ECM which supports tendons, skin, cartilage, bones, ligaments and cornea tissue. ${ }^{11-13}$ Therefore, it is considered as a proper matrix or scaffold. Collagen interaction with connective tissue cells transduces crucial signals for the regulation of cell adhesion, survival, proliferation, migration and differentiation. ${ }^{14}$ Collagen has many types but type I collagen is the most studied for tissue engineering and biomedical uses. ${ }^{15}$ Its properties including high mechanical strength, low antigenicity, good biocompatibility and ability of being cross-linked, make collagen an ideal biomaterials for tissue engineering applications. ${ }^{16,17}$ Laiva et al developed a scaffold with pro-angiogenic gene-activated properties to influence angiogenesis by producing paracrine angiogenic factors in wound healing. They combined nanoparticles of polyethyleneimine containing stromal derived factor- 1 alpha (SDF-1a) gene with a collagen-chondroitin sulfate scaffold. They evaluated the effect of this structure on mesenchymal stem cells (MSCs) angiogenic potential. The MSCs on scaffold showed SDF-1 a mRNA over-expression associated with VEGF and CXCR4 activation which are angiogenic factors. They conclude that combination of SDF-1a gene with collagen-based scaffolds can provide a suitable condition for angiogenic response during wound closure. ${ }^{18}$ Some of these applications are summarized in Table 1.

\section{Gelatin}

Gelatin is a natural polymer derived from collagen which is widely used for medical applications and pharmaceutical due to its biocompatibility and biodegradability in physiological environments. ${ }^{49,50}$ In addition, gelatin has low antigenicity in comparison to collagen which is shown antigenicity because of its animal origin. Gelatin is a denatured protein received by collagen processing using alkaline and acid. ${ }^{51,52}$ The alkaline process affects asparagine and glutamine amide groups and hydrolyses these group into carboxyl ones. Acidic treatment has little influence on the amide groups. Therefore, acidic treatment is electrically different from alkaline-processed gelatin. The different conditions of gelatin processing allow polyion complexation flexibility of a gelatin scaffold, carrier or hydrogel with either negatively or positively charged biomolecules and cells. ${ }^{49,53}$ Because of mentioned properties of gelatin, it is been used in engineering of various tissues and drug delivery applications. We summarize many of these applications in table. Nemati et al used alginate-gelatin microcapsules to provide an appropriate microenvironment for human umbilical vein endothelial cells (HUVECs) during a 5-day period. In vitro studies revealed promotion of HUVECs proliferation and cell survival. The expression of VEGFR-1, VEGFR-2, Tie-1 and Tie-2 were enhanced however it was not significant. They investigate the potential of the encapsulated cells in angiogenesis by implanting it in immune-compromised mouse model for 7 days. The result showed an increase of encapsulated cells angiogenic response in comparison to non-capsulated ones. They claimed that angiogenic response could be promoted by alginate-gelatin encapsulation. ${ }^{54}$ In Table 2, some of gelatin applications in tissue engineering are summarized.

\section{Chitosan}

Chitosan is a chitin-obtained cationic polymer consists of copolymers of $\mathrm{N}$-acetyl-D-glucosamine and $\beta$ $(1 \rightarrow 4)$-glucosamine. Chitin as a natural polysaccharide found in the cuticles of insects, shell of crustacean and fungi cell walls. Chitosan is the partially or fully deacetylated form of chitin ${ }^{71}$. The chitosan deacetylation degree is usually a range between $70 \%$ and $95 \%$, and the molecular weight is also between 10 to $1000 \mathrm{kDa} .{ }^{72}$ Its application in tissue engineering and drug delivery fields is wide ranging from cartilage, bone, vascular grafts and skin to substrates for cell culture. Biologically renewable, biocompatible, biodegradable, nontoxic and non-antigenic properties of chitosan make it a bio-functional useful biomaterial. ${ }^{52,73,74}$ In addition, hydroxyl and amino groups of chitosan can be modified chemically to provide a high chemical diversity. It also has bio-adhesive properties. ${ }^{72}$ Chitosan exhibits different behaviors at various $\mathrm{pH}$ levels. It doesn't dissolve at high $\mathrm{pH}$ while it is soluble at lower $\mathrm{pH}$ ranges. ${ }^{75}$ This property makes chitosan a suitable tool for delivery applications. The summarized applications of chitosan in tissue engineering exhibited in Table 3. Cheng et 
Table 1. Collagen Applications in Tissue Engineering

\begin{tabular}{|c|c|c|c|c|c|}
\hline Polymer & Condition & Cell Type & $\begin{array}{l}\text { Tissue Engineering } \\
\text { Application }\end{array}$ & In Vitro/In Vivo (Animal) & Reference \\
\hline Collagen & As sponge & Chondrocytes & Cartilage & $\begin{array}{l}\text { In vivo (implantation in } \\
\text { nude mice) }\end{array}$ & 19 \\
\hline Collagen & As gel & Stromal cells of bone marrow & Bone/cartilage & In vivo (mice) & 20 \\
\hline Collagen & As gel & - & Skin & In vivo (rabbit) & 21 \\
\hline Collagen & As gel & - & Angiogenesis & In vitro & 22 \\
\hline Collagen & As a gel in heparan sulfate matrix & - & Angiogenesis & In vivo (rat) & 23 \\
\hline Collagen & As a gel with gelatin microspheres & - & Adipose & In vivo (mice) & 24 \\
\hline Collagen & As sponge & Osteoblasts & Bone & $\begin{array}{l}\text { In vivo (defect in mice } \\
\text { skull) }\end{array}$ & 25 \\
\hline Collagen & Electrospun nanofibers & Bone marrow-derived MSCs & Bone & In vitro & 26 \\
\hline Collagen & As sponge and hydrogel & Human intervertebral disc cells & Intervertebral disc & In vitro & 27 \\
\hline Collagen & As sponge & Porcine third molar cells & Tooth & In vivo (rat) & 28 \\
\hline Collagen & As sponge & Autologous chondrocytes & Cartilage & In vivo (sheep) & 29 \\
\hline Collagen & As membrane & Chondrocytes & Cartilage & In vivo (rabbit) & 30 \\
\hline Collagen & As sponge & Human preadipocytes & Adipose & In vivo (nude mice) & 31 \\
\hline Collagen & Associated with GAG & Bone marrow-derived MSCs & Cardiovascular & In vivo (rat) & 32 \\
\hline Collagen & Scaffold & Human smooth muscle cells & Urogenital & In vivo (nude mice) & 33 \\
\hline Collagen & As gel & $\begin{array}{l}\text { Glomerular mesangial and epithelial } \\
\text { cells }\end{array}$ & $\begin{array}{l}\text { Glomerular tissue of } \\
\text { kidney }\end{array}$ & In vitro & 34 \\
\hline Collagen & Fibrous scaffold & Meniscus cells & $\begin{array}{l}\text { Meniscus tissue } \\
\text { generation }\end{array}$ & In vitro & 35 \\
\hline Collagen & $\begin{array}{l}\text { Electrospun fibers composed by poly(L- } \\
\text { lactide-co-caprolactone) }\end{array}$ & $\begin{array}{l}\text { Autologous tracheal epithelial cells } \\
\text { and chondrocytes }\end{array}$ & Trachea & In vivo (rat) & 36 \\
\hline Collagen & As hydrogel & MSCs and MCs & Meniscal tissue & In vitro & 37 \\
\hline Collagen & $\begin{array}{l}\text { Freeze dried porous scaffold composed } \\
\text { by } \beta \text {-tricalcium phosphate }\end{array}$ & MSCs & Bone & In vitro & 38 \\
\hline Collagen & As films composed by silk fibroin & $\begin{array}{l}\text { Adipose-derived stem cells and } \\
\text { human osteoblasts }\end{array}$ & Bone & In vitro & 39 \\
\hline Collagen & $\begin{array}{l}\text { Associated with alginate as bioink for } \\
\text { three-dimensional (3D) cell printing }\end{array}$ & Chondrocytes & Cartilage & In vitro & 40 \\
\hline Collagen & $\begin{array}{l}\text { Composed with hydroxyapatite and } \\
\text { PLGA and alginate incorporated } \\
\text { microparticles }\end{array}$ & Osteoblasts & Bone & In vitro/In vivo (rat) & 41 \\
\hline Collagen & $\begin{array}{l}\text { As hydrogel composed with } \\
\text { hydroxyapatite and alginate }\end{array}$ & Chondrocytes & Osteochondral & In vitro & 42 \\
\hline Collagen & $\begin{array}{l}\text { Composed with bioglass and } \\
\text { phosphatidylserine }\end{array}$ & rMSCs & Bone & In vitro/In vivo (rat) & 43 \\
\hline Collagen & Membrane scaffold Composed with GAG & Tendon cells & Tendon & In vitro & 44 \\
\hline Collagen & $\begin{array}{l}\text { Electrospun scaffold composed with } \\
\text { human tropoelastin }\end{array}$ & - & Skin & In vitro & 45 \\
\hline Collagen & Composed with bacterial cellulose & Osteogenic cells & Bone & In vitro & 46 \\
\hline Collagen & Composed with elastin-like polypeptide & MC3T3-E1 pre-osteoblast cells & Bone & In vitro & 47 \\
\hline Collagen & $\begin{array}{l}\text { Scaffold with a cement of calcium } \\
\text { phosphate }\end{array}$ & Umbilical cord stem cells & Bone & In vitro & 48 \\
\hline
\end{tabular}

Abbreviations: MSCs, mesenchymal stem cells; MCs, meniscus cells; rMSCs, Rat MSCs

al carried out a study to construct a thermo-sensitive hydrogel of chitosan/gelatin composition that is suitable for angiogenic applications by sustained release of adipose-derived stem cells which is a result of gelatin gradual degradation. In vitro studies revealed a significant concentration of VEGF in the supernatant of chitosan/gelatin hydrogels containing adipose-derived stem cells. Tube-like structures were formed in co-culture of the encapsulated adipose-derived stem cells and SVEC4-10 endothelial cells. This result demonstrates the potential of chitosan/gelatin hydrogel in inducing angiogenesis. ${ }^{76}$ Recent applications of chitosan are summarized in Table 3.

\section{Silk}

Silk is a protein biopolymer produced by spiders, silkworms, mites, scorpions and flies. ${ }^{98}$ Spider silk is an interesting biomaterial that is weightless, elastic and strong that is comparable to the best fibers synthetized by new technology 
Table 2. Gelatin Applications in Tissue Engineering

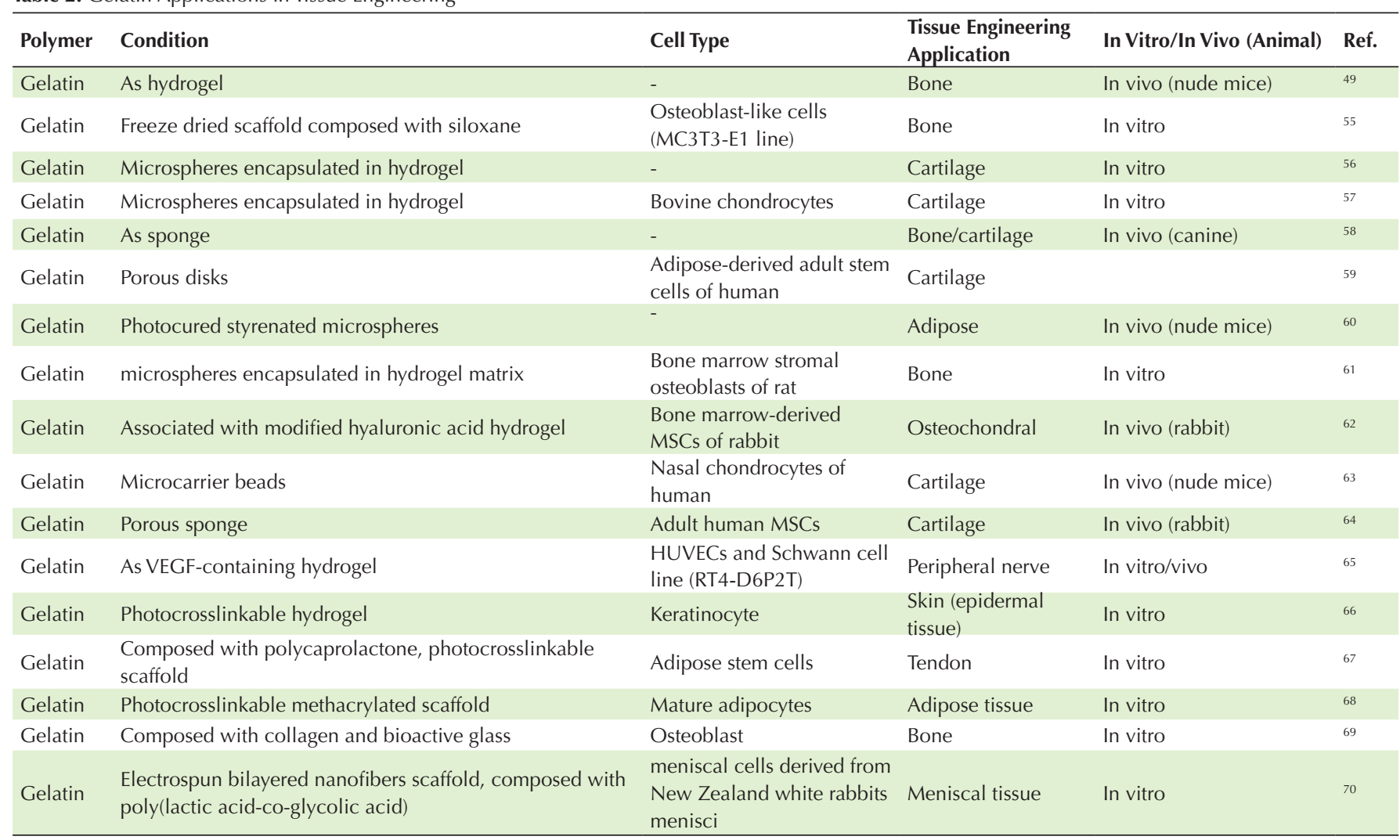

Abbreviations: HUVECs, human umbilical vein endothelial cells; MSCs, mesenchymal stem cells.

Table 3. Chitosan Application in Tissue Engineering

\begin{tabular}{|c|c|c|c|c|c|}
\hline Polymer & Condition & Cell Type & $\begin{array}{l}\text { Tissue Engineering } \\
\text { Application }\end{array}$ & In Vitro/In Vivo (Animal) & Ref. \\
\hline Chitosan & Photopolymerizable hydrogels associated with collagen & Mouse BMSCs & Bone & In vitro & 77 \\
\hline Chitosan & A TCP/ chitosan hydrogel & - & Bone & In vivo (rat) & 78 \\
\hline Chitosan & Freeze-dried scaffolds & Rat calvarial osteoblasts & Bone & In vitro & 79 \\
\hline Chitosan & $\begin{array}{l}\text { Composed with collagen scaffolds periodontal TGF- } \beta 1 \\
\text { plasmid Human }\end{array}$ & $\begin{array}{l}\text { Periodontal ligament cells } \\
\text { of human }\end{array}$ & Periodontal bone & In vivo (nude mice) & 80 \\
\hline Chitosan & Freeze-dried sponge & $\begin{array}{l}\text { Fetal rat calvarial } \\
\text { osteoblastic cells }\end{array}$ & Periodontal bone & $\begin{array}{l}\text { In vivo (calvarial defect } \\
\text { of rat) }\end{array}$ & 81 \\
\hline Chitosan & Composed with gelatin, freeze-dried scaffolds & $\begin{array}{l}\text { Rabbit articular } \\
\text { chondrocytes }\end{array}$ & Cartilage & In vitro & 82 \\
\hline \multirow{2}{*}{$\begin{array}{l}\text { Chitosan } \\
\text { Chitosan }\end{array}$} & microspheres in chitosan freeze-dried scaffolds & $\begin{array}{l}\text { Porcine articular } \\
\text { chondrocytes }\end{array}$ & Cartilage & In vitro & 83 \\
\hline & $\begin{array}{l}\text { microspheres in chondroitin sulfate-collagen-chitosan } \\
\text { freeze-dried scaffolds }\end{array}$ & $\begin{array}{l}\text { Rabbit articular } \\
\text { chondrocytes }\end{array}$ & Cartilage & In vitro & 84 \\
\hline Chitosan & As hydrogel, composed with glycerol phosphate & - & Osteochondral & In vivo (rabbit) & 85 \\
\hline Chitosan & As hydrogels & - & Vascularization & In vivo (rabbit) & 87 \\
\hline Chitosan & As hydrogel & - & Skin & In vivo (rat burn wound) & 88 \\
\hline Chitosan & As photo cross-linked hydrogel & - & Skin & $\begin{array}{l}\text { In vivo (mice full- } \\
\text { thickness skin incisions) }\end{array}$ & 89 \\
\hline $\begin{array}{l}\text { Chitosan/ } \\
\text { chitin }\end{array}$ & Tubular device with PLGA microspheres & Mice neural stem cells & $\begin{array}{l}\text { Peripheral nerve } \\
\text { regeneration }\end{array}$ & In vitro & 90 \\
\hline Chitosan & $\begin{array}{l}\text { As injectable hydrogel, composed with chondroitin } \\
\text { sulfate }\end{array}$ & Articular chondrocytes & Cartilage & In vitro & 91 \\
\hline Chitosan & $\begin{array}{l}\text { As scaffold, containing calcium polyphosphate and } \\
\text { pigeonite }\end{array}$ & MSCs & Bone & In vivo (rat) & 92 \\
\hline Chitosan & Composed with gelatin as macroporous scaffold & Human dermal fibroblasts & Blood vessel & In vitro & 93 \\
\hline $\begin{array}{l}\text { Hydroxyethyl } \\
\text { chitosan }\end{array}$ & $\begin{array}{l}\text { Hydrogel scaffolds with bubble-like porous structure } \\
\text { composed with cellulose }\end{array}$ & $\begin{array}{l}\text { Osteoblastic MC3T3-E1 } \\
\text { cells }\end{array}$ & Bone & In vitro & 94 \\
\hline Chitosan & Composed with nano-hydroxyapatite & Human bone MSCs & Bone & In vitro & 95 \\
\hline Chitosan & $\begin{array}{l}\text { Composed with poly(lactic acid) as a nano-fibrous } \\
\text { scaffolds }\end{array}$ & Cardiomyocyte & Cardiac tissue & In vitro & 96 \\
\hline
\end{tabular}

Abbreviations: HUVECs, human umbilical vein endothelial cells; MSCs, mesenchymal stem cells; BMSCs, bone marrow stromal cells. 
in terms of mechanical properties. ${ }^{99}$ It is also a bio-degradable material and environmentally safe. Because of the limited amount of spider silk, silk fibroin as a natural polymer which produced by silkworms is a good alternative. ${ }^{100,101}$ Sericin and fibroin are the major components of it. Fibroin, a fibrous protein creating the silk core, is composed of composed of fibroin Light chain, fibroin heavy chain and fibrohexamerin. ${ }^{102}$ Excellent mechanical properties, biocompatibility and slow degradability make this material interesting ${ }^{103,104}$. Recently, silk is used as a biomaterial in corneal tissue engineering due to its transparency potential. Some of applications are mentioned in Table 4. Liu et al fabricated a Porous scaffold composed of basic FGF-immobilized silk fibroin. Proliferation and growth of L929 cells were improved on bFGF-immobilized silk fibroin scaffolds. In vivo studies contained implantation of the scaffold into the skin defect of rat that displayed significant re-epithelialization and skin regeneration. Formation of new vessels and deposition of collagen after 4-week treatment, showed the potential of these scaffold in angiogenesis and tissue regeneration. ${ }^{105}$ Table 4 shows silk fibroin applications in regenerative medicine studies.

\section{Fibrin}

The applications of this natural polymer are well developed because of its innate ability to cellular interaction induction and scaffold remodeling in comparison to synthetic scaffolds. ${ }^{135}$ Fibrin-based materials biochemical specifications make them ideal for drug and cell delivery. It can also be harvested autologous that provides an immuno-compatible carrier for drug, cell and active biomolecules delivery. ${ }^{136,137}$ Keratinocytes, tracheal epithelial cells, murine embryonic stem cells, urothelial cells and mesenchymal progenitor cells are examples that could be carried by this biomaterial. ${ }^{138-140}$ It is also very used in chondrocytes encapsulation for tissue

Table 4. Silk fibroin applications in tissue engineering

\begin{tabular}{|c|c|c|c|c|c|}
\hline Polymer & Condition & Cell Type & $\begin{array}{l}\text { Tissue Engineering } \\
\text { Application }\end{array}$ & $\begin{array}{l}\text { In Vitro/In Vivo } \\
\text { (Animal) }\end{array}$ & Ref. \\
\hline Silk fibroin & Fibre scaffolds & $\begin{array}{l}\text { Bone marrow-derived } \\
\text { mesenchymal }\end{array}$ & Bone & In vitro & 106 \\
\hline Silk fibroin & As hydrogel & Osteoblasts & Bone & In vivo (rabbit) & 107 \\
\hline Silk fibroin & Electrospun align net & Endothelial cells & Angiogenesis & In vitro & 108 \\
\hline Silk fibroin & Porous scaffolds & MSCs & Cartilage & In vitro & 109 \\
\hline Silk fibroin & Electrospun fiber scaffolds & Fibroblasts and keratinocytes & Wound dressing & In vitro & 110 \\
\hline Silk fibroin & Composed with collagen & Hepatocytes & Liver & In vitro & 111 \\
\hline Silk fibroin & Multi fiber matrix & Bone marrow-derived MSCs & $\begin{array}{l}\text { Anterior crucial } \\
\text { ligament }\end{array}$ & In vitro & 112 \\
\hline Silk fibroin & Electrospun scaffold & Human MSCs (hMSCs) & - & In vitro & 113 \\
\hline Silk & Biohybrid scaffold, composed with PLGA & Mesenchymal progenitor cells & Ligament/tendon & In vitro & 114 \\
\hline Silk fibroin & $\begin{array}{l}\text { Macro/microporous scaffolds prepared } \\
\text { byobtained by combining the salt-leaching and } \\
\text { freeze-drying methods }\end{array}$ & - & $\begin{array}{l}\text { Articular cartilage } \\
\text { and meniscus }\end{array}$ & In vitro & 115 \\
\hline Silk fibroin & Scaffold & Human adipose-derived stem cells & Bone & In vitro & 116 \\
\hline Silk fibroin & Electrospun sulfated nanofibrous scaffolds & $\begin{array}{l}\text { Endothelial cells and smooth } \\
\text { muscle cells }\end{array}$ & Vascular tissue & In vitro & 117 \\
\hline Silk fibroin & Lactose conjugated & $\begin{array}{l}\text { Rat hepatocytes, FLC-4, and } \\
\text { HepG2 cell lines }\end{array}$ & Hepatic tissue & In vitro & $101,118,119$ \\
\hline Silk fibroin & Composed with alginate, chitin or collagen & $\begin{array}{l}\text { Human oral/epidermal } \\
\text { keratinocytes and fi broblasts }\end{array}$ & Skin & In vivo (rat) & $120-123$ \\
\hline Silk fibroin & Scaffold & Rat olfactory ensheathing cells & Spinal cord tissue & In vitro & 124,125 \\
\hline Silk fibroin & Scaffold & Fibroblasts and chondrocytes & Tracheal tissue & In vivo (rabbit) & 126 \\
\hline Silk fibroin & Scaffold composed with chitosan & Fibroblasts and chondrocytes & Tracheal tissue & In vivo (rat) & 127 \\
\hline Silk fibroin & Scaffold & $\begin{array}{l}\text { Human smooth muscle cells and } \\
\text { myoblasts }\end{array}$ & Muscle tissue & In vitro & 101 \\
\hline Silk fibroin & Scaffold & $\begin{array}{l}\text { Human tympanic membrane } \\
\text { keratinocytes }\end{array}$ & Eardrum tissue & In vitro & 128,129 \\
\hline Silk fibroin & Containing cardiac tissue-derived ECM & $\begin{array}{l}\text { HL-1 atrial cardiomyocytes and } \\
\text { human embryonic stem cell- } \\
\text { derived cardiomyocytes }\end{array}$ & Cardiac tissue & In vitro/vivo (rat) & 130 \\
\hline Silk fibroin & As nano-hydroxyapatite composite hydrogels & Osteoblastic cells & Bone & In vitro & 131 \\
\hline Silk fibroin & $\begin{array}{l}\text { bFGF-incorporated porous scaffolds produced } \\
\text { by freeze-drying }\end{array}$ & Dental pulp stem cells & Dental pulp & In vitro & 132 \\
\hline Silk fibroin & Composed with poly (glycerol sebacate) & $\begin{array}{l}\text { Dorsal fibroblasts of newborn } \\
\text { littermates of } \mathrm{C} 57 \mathrm{BL} / 6 \text { mice }\end{array}$ & Skin & In vitro & 133 \\
\hline Silk fibroin & Electrospun scaffold & Bone marrow MSCs & Sciatic nerve & In vivo (dog) & 134 \\
\hline
\end{tabular}

Abbreviations: HUVECs, human umbilical vein endothelial cells; MSCs, mesenchymal stem cells; BMSCs, bone marrow stromal cells; hMSCs, human MSCs; ECM, extracellular matrix. 
engineering of cartilage. Rapid degradation of fibrin can be considered as a disadvantage in tissue engineering. Therefore, improving composition of fibrin is an important issue to produce a scaffold system with appropriate mechanical properties. ${ }^{141-143}$ An investigation was performed by Dohle et al to establish co-culture system of primary osteoblasts and outgrowth endothelial cells within injectable platelet-rich fibrin matrices. They were in an effort to determine the effect of platelet-rich fibrin on angiogenesis and wound healing by activating endothelial cells in this system. Histological studies indicated vessel-like structures formation after 7 days culturing. Expression of the VEGF, as a pro-angiogenic factor, was increased on the mRNA and protein levels. Therefore, platelet-rich fibrin might be ideal for wound healing through promoting angiogenesis. ${ }^{144}$ Applications of fibrin-based constructs in tissue engineering are summarized in Table 5.

\section{Conclusion}

We reviewed different usages of some natural polymers in tissue engineering based on previous researches. Among the materials, polymers have been widely applied and have excellent potential to regenerate tissues due to their flexible features. ${ }^{166}$ As mentioned one of the issues in the tissue regeneration is to provide blood supplying. ${ }^{1}$ For this purpose, the quality of the regenerated vascular network is more important than the quantity. In other words, amount of perfused blood through a vascular network is the criterion, not just the number of vessels. Therefore, the importance of the vascular structure organization and maturation is clear. On the other hand, over-stimulating of angiogenesis leads to the creation of many unorganized vessels which are poorly perfused and have inefficient performance. ${ }^{167}$ Organization of vascular structures is not the only factor that determines the success chances of engineered tissues, but it seems to be a basic principle. ${ }^{168}$ Tissue engineering is in an effort to focus on vascular cells patterning in the target tissue to control the organization and maturation of vascular structures.

Incorporation of active bio-molecules like growth factors, angiogenic factors and elements is a novel strategy that is highly useful to improve tissue regeneration by improving angiogenesis, ${ }^{169}$ but achieving a tissue with normal and functional vascular structures is still a challenge.

Table 5. Silk Fibroin Applications in Tissue Engineering

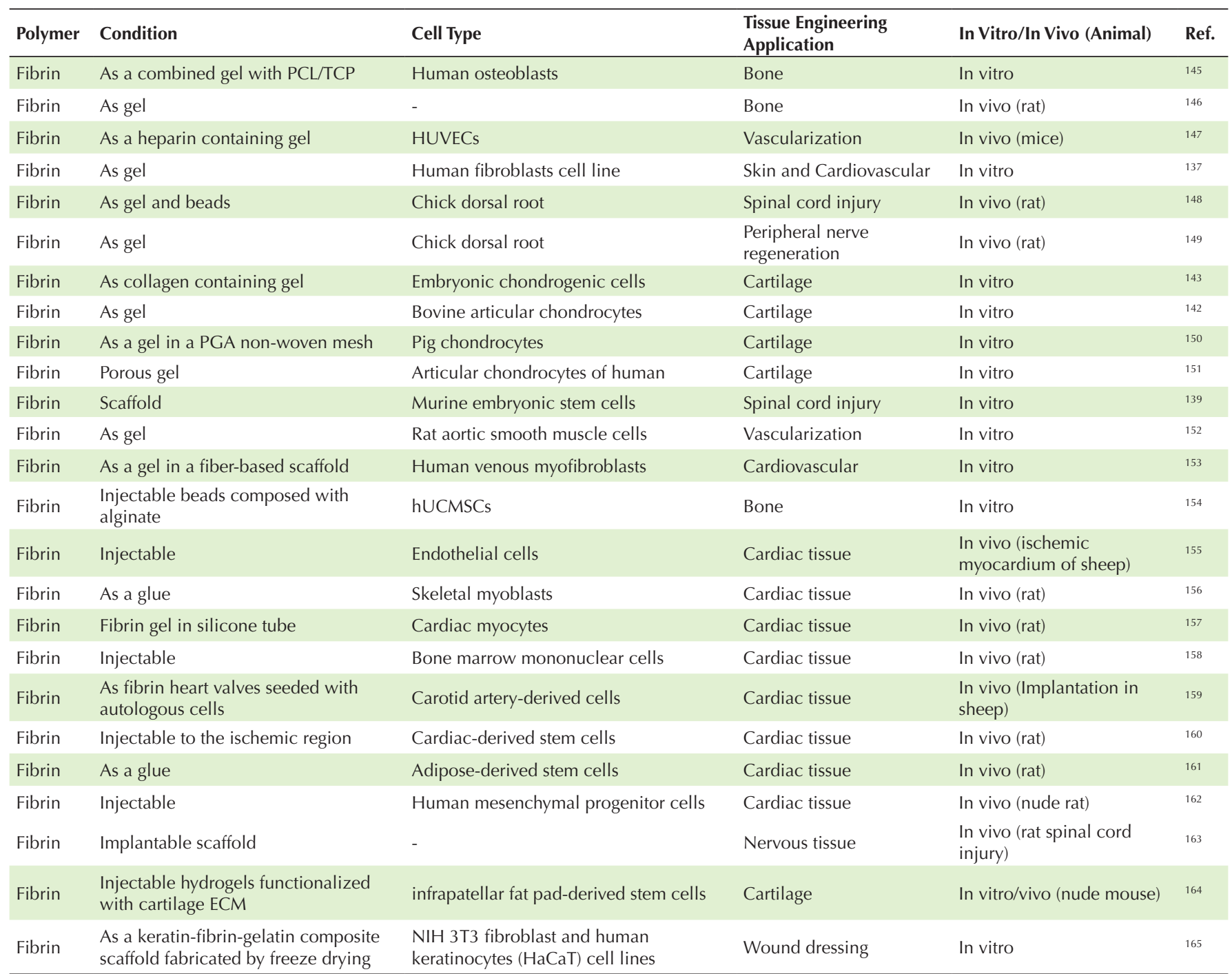

Abbreviations: hUCMSCs; human umbilical cord MSCs; HUVECs, human umbilical vein endothelial cells; MSCs, mesenchymal stem cells; ECM, extracellular matrix. 
Authors' Contributions

All authors contributed equally to this research.

\section{Conflict of Interest Disclosures}

The authors declare they have no conflicts of interest.

\section{References}

1. Kargozar S, Baino F, Hamzehlou S, Hill RG, Mozafari M. Bioactive Glasses: Sprouting Angiogenesis in Tissue Engineering. Trends Biotechnol. 2018;36(4):430-444. doi:10.1016/j. tibtech.2017.12.003.

2. Malafaya PB, Silva GA, Reis RL. Natural-origin polymers as carriers and scaffolds for biomolecules and cell delivery in tissue engineering applications. Adv Drug Deliv Rev. 2007;59(4-5):207233. doi:10.1016/j.addr.2007.03.012.

3. Murphy WL, Dennis RG, Mooney DJ. Tissue engineering scaffolds. Google Patents; 2009.

4. Czernuszka J, Sachlos E, Derby B, Reis N, Ainsley C. Tissue engineering scaffolds. Google Patents; 2004.

5. Sachlos E, Czernuszka JT. Making tissue engineering scaffolds work. Review: the application of solid freeform fabrication technology to the production of tissue engineering scaffolds. Eur Cell Mater. 2003;5:29-39; discussion 39-40.

6. Rogina A. Electrospinning process: Versatile preparation method for biodegradable and natural polymers and biocomposite systems applied in tissue engineering and drug delivery. Appl Surf Sci. 2014;296:221-230. doi:10.1016/j.apsusc.2014.01.098.

7. Pina S, Oliveira JM, Reis RL. Natural-based nanocomposites for bone tissue engineering and regenerative medicine: a review. Adv Mater. 2015;27(7):1143-1169. doi:10.1002/adma.201403354.

8. Caliari SR, Burdick JA. A practical guide to hydrogels for cell culture. Nat Methods. 2016;13(5):405-414. doi:10.1038/ nmeth.3839.

9. Laschke MW, Harder $\mathrm{Y}$, Amon M, et al. Angiogenesis in tissue engineering: breathing life into constructed tissue substitutes. Tissue Eng. 2006;12(8):2093-2104. doi:10.1089/ten.2006.12.2093.

10. Soker S, Machado M, Atala A. Systems for therapeutic angiogenesis in tissue engineering. World J Urol. 2000;18(1):1018. doi:10.1007/pl00007070.

11. Chevallay B, Herbage D. Collagen-based biomaterials as 3D scaffold for cell cultures: applications for tissue engineering and gene therapy. Med Biol Eng Comput. 2000;38(2):211-218. doi:10.1007/bf02344779.

12. Eyre DR. Collagen: molecular diversity in the body's protein scaffold. Science. 1980;207(4437):1315-1322. doi:10.1126/ science.207.4437.1315.

13. Goodarzi H, Jadidi K, Pourmotabed S, Sharifi E, Aghamollaei H. Preparation and in vitro characterization of cross-linked collagengelatin hydrogel using EDC/NHS for corneal tissue engineering applications. Int J Biol Macromol. 2018; In Press. doi:10.1016/j. ijbiomac.2018.12.125.

14. Yang C, Hillas PJ, Baez JA, et al. The application of recombinant human collagen in tissue engineering. BioDrugs. 2004;18(2):103119. doi:10.2165/00063030-200418020-00004.

15. Kivirikko KI. Collagen biosynthesis: a mini-review cluster. Matrix Biol. 1998;16(7):355-356. doi:10.1016/S0945-053X(98)90008-7.

16. Davison PF, Levine L, Drake MP, Rubin A, Bump S. The serologic specificity of tropocollagen telopeptides. J Exp Med. 1967;126(2):331-346. doi:10.1084/jem.126.2.331.

17. Lynn AK, Yannas IV, Bonfield W. Antigenicity and immunogenicity of collagen. J Biomed Mater Res B Appl Biomater. 2004;71(2):343354. doi:10.1002/jbm.b.30096.

18. Laiva AL, Raftery RM, Keogh MB, O'Brien FJ. Pro-angiogenic impact of SDF-1alpha gene-activated collagen-based scaffolds in stem cell driven angiogenesis. Int J Pharm. 2018;544(2):372-379. doi:10.1016/j.ijpharm.2018.03.032.

19. Fujisato T, Sajiki T, Liu Q, Ikada Y. Effect of basic fibroblast growth factor on cartilage regeneration in chondrocyte-seeded collagen sponge scaffold. Biomaterials. 1996;17(2):155-162. doi:10.1016/0142-9612(96)85760-7.

20. Xu XL, Lou J, Tang T, et al. Evaluation of different scaffolds for BMP2 genetic orthopedic tissue engineering. J Biomed Mater Res B Appl Biomater. 2005;75(2):289-303. doi:10.1002/jbm.b.30299.

21. Chandler LA, Gu DL, Ma C, et al. Matrix-enabled gene transfer for cutaneous wound repair. Wound Repair Regen. 2000;8(6):473479. doi:10.1046/j.1524-475x.2000.00473.x.

22. Koch S, Yao C, Grieb G, Prevel P, Noah EM, Steffens GC. Enhancing angiogenesis in collagen matrices by covalent incorporation of VEGF. J Mater Sci Mater Med. 2006;17(8):735-741. doi:10.1007/ s10856-006-9684-x.

23. Pieper JS, Hafmans T, van Wachem PB, et al. Loading of collagenheparan sulfate matrices with bFGF promotes angiogenesis and tissue generation in rats. J Biomed Mater Res. 2002;62(2):185-194. doi:10.1002/jbm.10267.

24. Vashi AV, Abberton KM, Thomas GP, et al. Adipose tissue engineering based on the controlled release of fibroblast growth factor-2 in a collagen matrix. Tissue Eng. 2006;12(11):3035-3043. doi:10.1089/ten.2006.12.3035.

25. Xiao Y, Qian H, Young WG, Bartold PM. Tissue engineering for bone regeneration using differentiated alveolar bone cells in collagen scaffolds. Tissue Eng. 2003;9(6):1167-1177. doi:10.1089/10763270360728071.

26. Shih YR, Chen CN, Tsai SW, Wang YJ, Lee OK. Growth of mesenchymal stem cells on electrospun type I collagen nanofibers. Stem Cells. 2006;24(11):2391-2397. doi:10.1634/ stemcells.2006-0253.

27. Gruber HE, Hoelscher GL, Leslie K, Ingram JA, Hanley EN, Jr. Three-dimensional culture of human disc cells within agarose or a collagen sponge: assessment of proteoglycan production. Biomaterials. 2006;27(3):371-376. doi:10.1016/j. biomaterials.2005.06.032.

28. Sumita $\mathrm{Y}$, Honda MJ, Ohara $\mathrm{T}$, et al. Performance of collagen sponge as a 3-D scaffold for tooth-tissue engineering. Biomaterials. 2006;27(17):3238-3248. doi:10.1016/j. biomaterials.2006.01.055.

29. Dorotka R, Bindreiter U, Macfelda K, Windberger U, Nehrer S. Marrow stimulation and chondrocyte transplantation using a collagen matrix for cartilage repair. Osteoarthritis Cartilage. 2005;13(8):655-664. doi:10.1016/j.joca.2005.04.001.

30. De Franceschi L, Grigolo B, Roseti L, et al. Transplantation of chondrocytes seeded on collagen-based scaffold in cartilage defects in rabbits. J Biomed Mater Res A. 2005;75(3):612-622. doi:10.1002/jbm.a.30471.

31. Hemmrich K, von Heimburg D, Rendchen R, Di Bartolo C, Milella E, Pallua N. Implantation of preadipocyte-loaded hyaluronic acid-based scaffolds into nude mice to evaluate potential for soft tissue engineering. Biomaterials. 2005;26(34):7025-7037. doi:10.1016/j.biomaterials.2005.04.065.

32. Xiang Z, Liao R, Kelly MS, Spector M. Collagen-GAG scaffolds grafted onto myocardial infarcts in a rat model: a delivery vehicle for mesenchymal stem cells. Tissue Eng. 2006;12(9):2467-2478. doi:10.1089/ten.2006.12.2467.

33. Danielsson C, Ruault S, Basset-Dardare A, Frey P. Modified collagen fleece, a scaffold for transplantation of human bladder smooth muscle cells. Biomaterials. 2006;27(7):1054-1060. doi:10.1016/j.biomaterials.2005.07.027.

34. Wang PC, Takezawa T. Reconstruction of renal glomerular tissue using collagen vitrigel scaffold. J Biosci Bioeng. 2005;99(6):529540. doi:10.1263/jbb.99.529.

35. Baek J, Sovani S, Choi W, Jin S, Grogan SP, D'Lima DD. Meniscal Tissue Engineering Using Aligned Collagen Fibrous Scaffolds: Comparison of Different Human Cell Sources. Tissue Eng Part A. 2018;24(1-2):81-93. doi:10.1089/ten.TEA.2016.0205.

36. Wu T, Zheng $\mathrm{H}$, Chen J, et al. Application of a bilayer tubular scaffold based on electrospun poly (I-lactide-co-caprolactone)/ collagen fibers and yarns for tracheal tissue engineering. J Mater 
Chem B. 2017;5(1):139-150. doi:10.1039/C6TB02484J.

37. Kremer A, Ribitsch I, Reboredo J, et al. Three-Dimensional Coculture of Meniscal Cells and Mesenchymal Stem Cells in Collagen Type I Hydrogel on a Small Intestinal Matrix-A Pilot Study Toward Equine Meniscus Tissue Engineering. Tissue Eng Part A. 2017;23(9-10):390-402. doi:10.1089/ten.TEA.2016.0317.

38. Baheiraei N, Nourani MR, Mortazavi SMJ, et al. Development of a bioactive porous collagen/beta-tricalcium phosphate bone graft assisting rapid vascularization for bone tissue engineering applications. J Biomed Mater Res A. 2018;106(1):73-85. doi:10.1002/jbm.a.36207.

39. Sayin E, Rashid RH, Rodriguez-Cabello JC, Elsheikh A, Baran ET, Hasirci V. Human adipose derived stem cells are superior to human osteoblasts (HOB) in bone tissue engineering on a collagenfibroin-ELR blend. Bioact Mater. 2017;2(2):71-81. doi:10.1016/j. bioactmat.2017.04.001.

40. Yang X, Lu Z, Wu H, Li W, Zheng L, Zhao J. Collagen-alginate as bioink for three-dimensional (3D) cell printing based cartilage tissue engineering. Mater Sci Eng C Mater Biol Appl. 2018;83:195201. doi:10.1016/j.msec.2017.09.002.

41. Quinlan E, Lopez-Noriega A, Thompson E, Kelly HM, Cryan SA, O'Brien FJ. Development of collagen-hydroxyapatite scaffolds incorporating PLGA and alginate microparticles for the controlled delivery of rhBMP-2 for bone tissue engineering. J Control Release. 2015;198:71-79. doi:10.1016/j.jconrel.2014.11.021.

42. Zheng L, Jiang X, Chen X, Fan H, Zhang X. Evaluation of novel in situ synthesized nano-hydroxyapatite/collagen/alginate hydrogels for osteochondral tissue engineering. Biomed Mater. 2014;9(6):065004. doi:10.1088/1748-6041/9/6/065004.

43. Xu C, Su P, Chen X, et al. Biocompatibility and osteogenesis of biomimetic Bioglass-Collagen-Phosphatidylserine composite scaffolds for bone tissue engineering. Biomaterials. 2011;32(4):1051-1058. doi:10.1016/j.biomaterials.2010.09.068.

44. Caliari SR, Ramirez MA, Harley BA. The development of collagen-GAG scaffold-membrane composites for tendon tissue engineering. Biomaterials. 2011;32(34):8990-8998. doi:10.1016/j. biomaterials.2011.08.035.

45. Rnjak-Kovacina J, Wise SG, Li Z, et al. Electrospun synthetic human elastin:collagen composite scaffolds for dermal tissue engineering. Acta Biomater. 2012;8(10):3714-3722. doi:10.1016/j. actbio.2012.06.032.

46. Saska S, Teixeira LN, de Oliveira PT, et al. Bacterial cellulosecollagen nanocomposite for bone tissue engineering. J Mater Chem. 2012;22(41):22102-22112. doi:10.1039/C2JM33762B.

47. Amruthwar SS, Janorkar AV. In vitro evaluation of elastinlike polypeptide-collagen composite scaffold for bone tissue engineering. Dent Mater. 2013;29(2):211-220. doi:10.1016/j. dental.2012.10.003.

48. Thein-Han W, Xu HH. Collagen-calcium phosphate cement scaffolds seeded with umbilical cord stem cells for bone tissue engineering. Tissue Eng Part A. 2011;17(23-24):2943-2954. doi:10.1089/ten.tea.2010.0674.

49. Ikada Y, Tabata Y. Protein release from gelatin matrices. Adv Drug Deliv Rev. 1998;31(3):287-301. doi:10.1016/S0169409X(97)00125-7.

50. Young S, Wong M, Tabata Y, Mikos AG. Gelatin as a delivery vehicle for the controlled release of bioactive molecules. J Control Release. 2005;109(1-3):256-274.doi:10.1016/j.jconrel.2005.09.023.

51. Djagny VB, Wang Z, Xu S. Gelatin: a valuable protein for food and pharmaceutical industries: review. Crit Rev Food Sci Nutr. 2001;41(6):481-492. doi:10.1080/20014091091904.

52. Shamosi A, Mehrabani D, Azami M, et al. Differentiation of human endometrial stem cells into endothelial-like cells on gelatin/ chitosan/bioglass nanofibrous scaffolds. Artif Cells Nanomed Biotechnol. 2017;45(1):163-173. doi:10.3109/21691401.2016.1 138493.

53. Sharifi E, Ebrahimi-Barough $\mathrm{S}$, Panahi $\mathrm{M}$, et al. In vitro evaluation of human endometrial stem cell-derived osteoblast-like cells' behavior on gelatin/collagen/bioglass nanofibers' scaffolds. J Biomed Mater Res A. 2016;104(9):2210-2219. doi:10.1002/ jbm.a.35748.

54. Nemati S, Rezabakhsh A, Khoshfetrat AB, et al. Alginategelatin encapsulation of human endothelial cells promoted angiogenesis in in vivo and in vitro milieu. Biotechnol Bioeng. 2017;114(12):2920-2930. doi:10.1002/bit.26395.

55. Ren L, Osaka A, Yu B, et al. Bioactive gelatin-siloxane hybrids as tissue engineering scaffold. Solid State Phenomena. 2006;111:1318. doi:10.4028/www.scientific.net/SSP.111.13.

56. Holland TA, Tabata Y, Mikos AG. Dual growth factor delivery from degradable oligo(poly(ethylene glycol) fumarate) hydrogel scaffolds for cartilage tissue engineering. J Control Release. 2005;101(1-3):111-125. doi:10.1016/j.jconrel.2004.07.004.

57. Park H, Temenoff JS, Holland TA, Tabata Y, Mikos AG. Delivery of TGF-beta1 and chondrocytes via injectable, biodegradable hydrogels for cartilage tissue engineering applications. Biomaterials. 2005;26(34):7095-7103. doi:10.1016/j. biomaterials.2005.05.083.

58. Okamoto T, Yamamoto $\mathrm{Y}$, Gotoh $\mathrm{M}$, et al. Cartilage regeneration using slow release of bone morphogenetic protein-2 from a gelatin sponge to treat experimental canine tracheomalacia: a preliminary report. ASAIO J. 2003;49(1):63-69. doi:10.1097/00002480200301000-00010.

59. Awad HA, Wickham MQ, Leddy HA, Gimble JM, Guilak F. Chondrogenic differentiation of adipose-derived adult stem cells in agarose, alginate, and gelatin scaffolds. Biomaterials. 2004;25(16):3211-3222. doi:10.1016/j.biomaterials.2003.10.045.

60. Masuda T, Furue M, Matsuda T. Photocured, styrenated gelatin-based microspheres for de novo adipogenesis through corelease of basic fibroblast growth factor, insulin, and insulinlike growth factor I. Tissue Eng. 2004;10(3-4):523-535. doi:10.1089/107632704323061889.

61. Payne RG, McGonigle JS, Yaszemski MJ, Yasko AW, Mikos AG. Development of an injectable, in situ crosslinkable, degradable polymeric carrier for osteogenic cell populations. Part 2. Viability of encapsulated marrow stromal osteoblasts cultured on crosslinking poly(propylene fumarate). Biomaterials. 2002;23(22):4373-4380. doi:10.1016/S0142-9612(02)00185-0.

62. Liu Y, Shu XZ, Prestwich GD. Osteochondral defect repair with autologous bone marrow-derived mesenchymal stem cells in an injectable, in situ, cross-linked synthetic extracellular matrix. Tissue Eng. 2006;12(12):3405-3416. doi:10.1089/ten.2006.12.3405.

63. Malda J, Kreijveld E, Temenoff JS, van Blitterswijk CA, Riesle J. Expansion of human nasal chondrocytes on macroporous microcarriers enhances redifferentiation. Biomaterials. 2003;24(28):5153-5161. doi:10.1016/S0142-9612(03)00428-9.

64. Ponticiello MS, Schinagl RM, Kadiyala S, Barry FP. Gelatinbased resorbable sponge as a carrier matrix for human mesenchymal stem cells in cartilage regeneration therapy. J Biomed Mater Res. 2000;52(2):246-255. doi:10.1002/10974636(200011)52:23.0.CO;2-W.

65. Gnavi S, di Blasio L, Tonda-Turo C, et al. Gelatin-based hydrogel for vascular endothelial growth factor release in peripheral nerve tissue engineering. J Tissue Eng Regen Med. 2017;11(2):459-470. doi:10.1002/term.1936.

66. Zhao X, Lang Q, Yildirimer L, et al. Photocrosslinkable Gelatin Hydrogel for Epidermal Tissue Engineering. Adv Healthc Mater. 2016;5(1):108-118. doi:10.1002/adhm.201500005.

67. Yang G, Lin H, Rothrauff BB, Yu S, Tuan RS. Multilayered polycaprolactone/gelatin fiber-hydrogel composite for tendon tissue engineering. Acta Biomater. 2016;35:68-76. doi:10.1016/j. actbio.2016.03.004

68. Huber B, Borchers K, Tovar GE, Kluger PJ. Methacrylated gelatin and mature adipocytes are promising components for adipose tissue engineering. J Biomater Appl. 2016;30(6):699-710. doi:10.1177/0885328215587450.

69. Sharifi E, Azami M, Kajbafzadeh AM, et al. Preparation of a 
biomimetic composite scaffold from gelatin/collagen and bioactive glass fibers for bone tissue engineering. Mater Sci Eng C Mater Biol Appl. 2016;59:533-541. doi:10.1016/j.msec.2015.09.037.

70. Li P, Zhang W, Yu H, et al. Applying Electrospun Gelatin/Poly(lactic acid-co-glycolic acid) Bilayered Nanofibers to Fabrication of Meniscal Tissue Engineering Scaffold. J Nanosci Nanotechnol. 2016;16(5):4718-4726. doi:10.1166/jnn.2016.12412.

71. Khor E, Lim LY. Implantable applications of chitin and chitosan. Biomaterials. 2003;24(13):2339-2349. doi:10.1016/S01429612(03)00026-7.

72. George M, Abraham TE. Polyionic hydrocolloids for the intestinal delivery of protein drugs: alginate and chitosan--a review. J Control Release. 2006;114(1):1-14. doi:10.1016/j.jconrel.2006.04.017.

73. Huang Y, Onyeri S, Siewe M, Moshfeghian A, Madihally SV. In vitro characterization of chitosan-gelatin scaffolds for tissue engineering. Biomaterials. 2005;26(36):7616-7627. doi:10.1016/j. biomaterials.2005.05.036.

74. Karimi S, Salahinejad E, Shari E, NourianA, Tayebi L. Bioperformance of chitosan/fluoride-doped diopside nanocomposite coatings deposited on medical stainless steel. Carbohydrate Polymers. 2018;202:600-610. doi:10.1016/j.carbpol.2018.09.022.

75. Patel VR, Amiji MM. Preparation and characterization of freezedried chitosan-poly(ethylene oxide) hydrogels for site-specific antibiotic delivery in the stomach. Pharm Res. 1996;13(4):588593. doi:10.1023/a:1016054306763.

76. Cheng NC, Lin WJ, Ling TY, Young TH. Sustained release of adiposederived stem cells by thermosensitive chitosan/gelatin hydrogel for therapeutic angiogenesis. Acta Biomater. 2017;51:258-267. doi:10.1016/j.actbio.2017.01.060.

77. Arakawa C, Ng R, Tan S, Kim S, Wu B, Lee M. Photopolymerizable chitosan-collagen hydrogels for bone tissue engineering. J Tissue Eng Regen Med. 2017;11(1):164-174. doi:10.1002/term.1896.

78. Delgado JJ, Evora C, Sanchez E, Baro M, Delgado A. Validation of a method for non-invasive in vivo measurement of growth factor release from a local delivery system in bone. J Control Release. 2006;114(2):223-229. doi:10.1016/j.jconrel.2006.05.026.

79. Lee JY, Nam SH, Im SY, et al. Enhanced bone formation by controlled growth factor delivery from chitosan-based biomaterials. J Control Release. 2002;78(1-3):187-197. doi:10.1016/S01683659(01)00498-9.

80. Zhang $\mathrm{Y}$, Cheng X, Wang J, et al. Novel chitosan/collagen scaffold containing transforming growth factor-beta1 DNA for periodontal tissue engineering. Biochem Biophys Res Commun. 2006;344(1):362-369. doi:10.1016/j.bbrc.2006.03.106.

81. Park YJ, Lee YM, Park SN, Sheen SY, Chung CP, Lee SJ. Platelet derived growth factor releasing chitosan sponge for periodontal bone regeneration. Biomaterials. 2000;21(2):153-159. doi:10.1016/S0142-9612(99)00143-X.

82. Guo T, Zhao J, Chang J, et al. Porous chitosan-gelatin scaffold containing plasmid DNA encoding transforming growth factor-beta1 for chondrocytes proliferation. Biomaterials. 2006;27(7):1095-1103. doi:10.1016/j.biomaterials.2005.08.015.

83. Kim SE, Park JH, Cho YW, et al. Porous chitosan scaffold containing microspheres loaded with transforming growth factor-beta1: implications for cartilage tissue engineering. J Control Release. 2003;91(3):365-374. doi:10.1016/S0168-3659(03)00274-8.

84. Lee JE, Kim KE, Kwon IC, et al. Effects of the controlled-released TGF-beta 1 from chitosan microspheres on chondrocytes cultured in a collagen/chitosan/glycosaminoglycan scaffold. Biomaterials. 2004;25(18):4163-4173. doi:10.1016/j. biomaterials.2003.10.057.

85. Chevrier A, Hoemann CD, Sun J, Buschmann MD. Chitosanglycerol phosphate/blood implants increase cell recruitment, transient vascularization and subchondral bone remodeling in drilled cartilage defects. Osteoarthritis Cartilage. 2007;15(3):316327. doi:10.1016/j.joca.2006.08.007.

86. Fujita $M$, Ishihara $M$, Simizu $M$, et al. Vascularization in vivo caused by the controlled release of fibroblast growth factor- 2 from an injectable chitosan/non-anticoagulant heparin hydrogel. Biomaterials. 2004;25(4):699-706. doi:10.1016/S01429612(03)00557-X.

87. Fujita $M$, Ishihara $M$, Morimoto $Y$, et al. Efficacy of photocrosslinkable chitosan hydrogel containing fibroblast growth factor-2 in a rabbit model of chronic myocardial infarction. J Surg Res. 2005;126(1):27-33. doi:10.1016/j.jss.2004.12.025.

88. Alemdaroglu C, Degim Z, Celebi N, Zor F, Ozturk S, Erdogan D. An investigation on burn wound healing in rats with chitosan gel formulation containing epidermal growth factor. Burns. 2006;32(3):319-327. doi:10.1016/j.burns.2005.10.015.

89. Obara K, Ishihara $M$, Ishizuka $T$, et al. Photocrosslinkable chitosan hydrogel containing fibroblast growth factor-2 stimulates wound healing in healing-impaired $\mathrm{db} / \mathrm{db}$ mice. Biomaterials. 2003;24(20):3437-3444. doi:10.1016/S0142-9612(03)00220-5.

90. Goraltchouk A, Scanga V, Morshead CM, Shoichet MS. Incorporation of protein-eluting microspheres into biodegradable nerve guidance channels for controlled release. J Control Release. 2006;110(2):400-407. doi:10.1016/j.jconrel.2005.10.019.

91. Fan $M$, Ma $Y$, Tan $H$, et al. Covalent and injectable chitosanchondroitin sulfate hydrogels embedded with chitosan microspheres for drug delivery and tissue engineering. Mater Sci Eng C Mater Biol Appl. 2017;71:67-74. doi:10.1016/j. msec.2016.09.068.

92. Dhivya S, Keshav Narayan A, Logith Kumar R, Viji Chandran S, Vairamani M, Selvamurugan N. Proliferation and differentiation of mesenchymal stem cells on scaffolds containing chitosan, calcium polyphosphate and pigeonite for bone tissue engineering. Cell Prolif. 2018;51(1). doi:10.1111/cpr.12408.

93. Badhe RV, Bijukumar D, Chejara DR, et al. A composite chitosangelatin bi-layered, biomimetic macroporous scaffold for blood vessel tissue engineering. Carbohydr Polym. 2017;157:12151225. doi:10.1016/j.carbpol.2016.09.095.

94. Wang Y, Qian J, Zhao N, Liu T, Xu W, Suo A. Novel hydroxyethyl chitosan/cellulose scaffolds with bubble-like porous structure for bone tissue engineering. Carbohydr Polym. 2017;167:44-51. doi:10.1016/j.carbpol.2017.03.030.

95. Atak BH, Buyuk B, Huysal $M$, et al. Preparation and characterization of amine functional nano-hydroxyapatite/ chitosan bionanocomposite for bone tissue engineering applications. Carbohydr Polym. 2017;164:200-213. doi:10.1016/j. carbpol.2017.01.100.

96. Liu Y, Wang S, Zhang R. Composite poly(lactic acid)/ chitosan nanofibrous scaffolds for cardiac tissue engineering. Int J Biol Macromol. 2017;103:1130-1137. doi:10.1016/j. ijbiomac.2017.05.101.

97. Grolik M, Kuzmicz D, Dobrowolski D, et al. Silicone-Modified Chitosan Membranes for Corneal Epithelium Tissue Engineering. J Biomater Tissue Eng. 2018;8(3):374-383. doi:10.1166/ jbt.2018.1746.

98. Altman GH, Diaz F, Jakuba C, et al. Silk-based biomaterials. Biomaterials. 2003;24(3):401-416. doi:10.1016/S01429612(02)00353-8.

99. Hinman MB, Jones JA, Lewis RV. Synthetic spider silk: a modular fiber. Trends Biotechnol. 2000;18(9):374-379. doi:10.1016/ S0167-7799(00)01481-5.

100. Tamada Y. New process to form a silk fibroin porous 3-D structure. Biomacromolecules. 2005;6(6):3100-3106. doi:10.1021/ bm050431f.

101. Kasoju N, Bora U. Silk fibroin in tissue engineering. Adv Healthc Mater. 2012;1(4):393-412. doi:10.1002/adhm.201200097.

102. Inoue S, Tanaka K, Arisaka F, Kimura S, Ohtomo K, Mizuno S. Silk fibroin of Bombyx mori is secreted, assembling a high molecular mass elementary unit consisting of $\mathrm{H}$-chain, L-chain, and P25, with a 6:6:1 molar ratio. J Biol Chem. 2000;275(51):40517-40528. doi:10.1074/jbc.M006897200.

103. Dal Pra I, Freddi G, Minic J, Chiarini A, Armato U. De novo engineering of reticular connective tissue in vivo by silk fibroin 
nonwoven materials. Biomaterials. 2005;26(14):1987-1999. doi:10.1016/j.biomaterials.2004.06.036.

104. Horan RL, Antle K, Collette AL, et al. In vitro degradation of silk fibroin. Biomaterials. 2005;26(17):3385-3393. doi:10.1016/j. biomaterials.2004.09.020.

105. Liu y, Qu J, Li M. Accelerated Vascularization of Silk Fibroin Scaffolds Through Immobilized Basic Fibroblast Growth Factor (bFGF). DEStech Transactions on Engineering and Technology Research Apetc; 2017. doi:10.12783/dtetr/apetc2017/11439.

106. Li C, Vepari C, Jin HJ, Kim HJ, Kaplan DL. Electrospun silkBMP-2 scaffolds for bone tissue engineering. Biomaterials. 2006;27(16):3115-3124.doi:10.1016/j.biomaterials.2006.01.022.

107. Fini M, Motta A, Torricelli P, et al. The healing of confined critical size cancellous defects in the presence of silk fibroin hydrogel. Biomaterials. 2005;26(17):3527-3536. doi:10.1016/j. biomaterials.2004.09.040.

108. Unger RE, Peters K, Wolf M, Motta A, Migliaresi C, Kirkpatrick CJ. Endothelialization of a non-woven silk fibroin net for use in tissue engineering: growth and gene regulation of human endothelial cells. Biomaterials. 2004;25(21):5137-5146. doi:10.1016/j. biomaterials.2003.12.040.

109. Wang Y, Kim UJ, Blasioli DJ, Kim HJ, Kaplan DL. In vitro cartilage tissue engineering with $3 \mathrm{D}$ porous aqueous-derived silk scaffolds and mesenchymal stem cells. Biomaterials. 2005;26(34):70827094. doi:10.1016/j.biomaterials.2005.05.022.

110. Min BM, Lee G, Kim SH, Nam YS, LeeTS, Park WH. Electrospinning of silk fibroin nanofibers and its effect on the adhesion and spreading of normal human keratinocytes and fibroblasts in vitro. Biomaterials. 2004;25(7-8):1289-1297. doi:10.1016/j. biomaterials.2003.08.045.

111. Lv Q, Feng Q, Hu K, Cui F. Three-dimensional fibroin/collagen scaffolds derived from aqueous solution and the use for HepG2 culture. Polymer. 2005;46(26):12662-12669. doi:10.1016/j. polymer.2005.10.137.

112. Altman GH, Horan RL, Lu HH, et al. Silk matrix for tissue engineered anterior cruciate ligaments. Biomaterials. 2002;23(20):41314141. doi:10.1016/S0142-9612(02)00156-4.

113. Meinel AJ, Kubow KE, Klotzsch E, et al. Optimization strategies for electrospun silk fibroin tissue engineering scaffolds. Biomaterials. 2009;30(17):3058-3067. doi:10.1016/j. biomaterials.2009.01.054.

114. Sahoo S, Toh SL, Goh JC. A bFGF-releasing silk/PLGA-based biohybrid scaffold for ligament/tendon tissue engineering using mesenchymal progenitor cells. Biomaterials. 2010;31(11):29902998. doi:10.1016/j.biomaterials.2010.01.004.

115. Yan LP, Oliveira JM, Oliveira AL, Caridade SG, Mano JF, Reis RL. Macro/microporous silk fibroin scaffolds with potential for articular cartilage and meniscus tissue engineering applications. Acta Biomater. 2012;8(1):289-301. doi:10.1016/j.actbio.2011.09.037.

116. Correia C, Bhumiratana S, Yan LP, et al. Development of silkbased scaffolds for tissue engineering of bone from human adipose-derived stem cells. Acta Biomater. 2012;8(7):2483-2492. doi:10.1016/j.actbio.2012.03.019.

117. Liu H, Li X, Zhou G, Fan H, Fan Y. Electrospun sulfated silk fibroin nanofibrous scaffolds for vascular tissue engineering. Biomaterials. 2011;32(15):3784-3793. doi:10.1016/j. biomaterials.2011.02.002.

118. Gotoh Y, Ishizuka Y, Matsuura T, Niimi S. Spheroid formation and expression of liver-specific functions of human hepatocellular carcinoma-derived FLC-4 cells cultured in lactose-silk fibroin conjugate sponges. Biomacromolecules. 2011;12(5):1532-1539. doi:10.1021/bm101495c.

119. Gotoh Y, Niimi S, Hayakawa T, Miyashita T. Preparation of lactosesilk fibroin conjugates and their application as a scaffold for hepatocyte attachment. Biomaterials. 2004;25(6):1131-1140. doi:10.1016/S0142-9612(03)00633-1.

120. Roh DH, Kang SY, Kim JY, et al. Wound healing effect of silk fibroin/alginate-blended sponge in full thickness skin defect of rat. J Mater Sci Mater Med. 2006;17(6):547-552. doi:10.1007/s10856- 006-8938-y.

121. Yoo CR, Yeo IS, Park KE, et al. Effect of chitin/silk fibroin nanofibrous bicomponent structures on interaction with human epidermal keratinocytes. Int J Biol Macromol. 2008;42(4):324334. doi:10.1016/j.jijbiomac.2007.12.004.

122. Hu K, Cui F, Lv Q, et al. Preparation of fibroin/recombinant human-like collagen scaffold to promote fibroblasts compatibility. J Biomed Mater Res A. 2008;84(2):483-490. doi:10.1002/ jbm.a.31440.

123. Yeo IS, Oh JE, Jeong L, et al. Collagen-based biomimetic nanofibrous scaffolds: preparation and characterization of collagen/silk fibroin bicomponent nanofibrous structures. Biomacromolecules. 2008;9(4):1106-1116. doi:10.1021/bm700875a.

124. Qian Y, Shen Y, Lu Z, et al. [Biocompatibility of silk fibroin nanofibers scaffold with olfactory ensheathing cells]. Zhongguo Xiu Fu Chong Jian Wai Ke Za Zhi. 2009;23(11):1365-1370.

125. Shen $Y$, Qian $Y$, Zhang $H$, et al. Guidance of olfactory ensheathing cell growth and migration on electrospun silk fibroin scaffolds. Cell Transplant. 2010;19(2):147-157. doi:10.3727/096368910x492616.

126. Ni Y, Zhao X, Zhou L, et al. Radiologic and histologic characterization of silk fibroin as scaffold coating for rabbit tracheal defect repair. Otolaryngol Head Neck Surg. 2008;139(2):256-261. doi:10.1016/j.otohns.2008.03.028.

127. Zang M, Zhang Q, Davis G, et al. Perichondrium directed cartilage formation in silk fibroin and chitosan blend scaffolds for tracheal transplantation. Acta Biomater. 2011;7(9):3422-3431. doi:10.1016/j.actbio.2011.05.012.

128. Levin B, Redmond SL, Rajkhowa R, Eikelboom RH, Marano RJ, Atlas MD. Preliminary results of the application of a silk fibroin scaffold to otology. Otolaryngol Head Neck Surg. 2010;142(3 Suppl 1):S33-35. doi:10.1016/j.otohns.2009.06.746.

129. Ghassemifar R, Redmond S, Zainuddin, Chirila TV. Advancing towards a tissue-engineered tympanic membrane: silk fibroin as a substratum for growing human eardrum keratinocytes. J Biomater Appl. 2010;24(7):591-606. doi:10.1177/0885328209104289.

130. Stoppel WL, Hu D, Domian IJ, Kaplan DL, Black LD, 3rd. Anisotropic silk biomaterials containing cardiac extracellular matrix for cardiac tissue engineering. Biomed Mater. 2015;10(3):034105. doi:10.1088/1748-6041/10/3/034105.

131. Ribeiro M, de Moraes MA, Beppu MM, et al. Development of silk fibroin/nanohydroxyapatite composite hydrogels for bone tissue engineering. Eur Polym J. 2015;67:66-77. doi:10.1016/j. eurpolymj.2015.03.056.

132. Yang JW, Zhang YF, Sun ZY, Song GT, Chen Z. Dental pulp tissue engineering with bFGF-incorporated silkfibroin scaffolds.J Biomater Appl. 2015;30(2):221-229. doi:10.1177/0885328215577296.

133. Zhang X, Jia C, Qiao X, Liu T, Sun K. Silk fibroin microfibers and chitosan modified poly (glycerol sebacate) composite scaffolds for skin tissue engineering. Polym Test. 2017;62:88-95. doi:10.1016/j. polymertesting.2017.06.012.

134. Xue C, Zhu H, Tan D, et al. Electrospun silk fibroin-based neural scaffold for bridging a long sciatic nerve gap in dogs. J Tissue Eng Regen Med. 2018;12(2):e1143-e1153. doi:10.1002/term.2449.

135. Barsotti MC, Felice F, Balbarini A, Di Stefano R. Fibrin as a scaffold for cardiac tissue engineering. Biotechnol Appl Biochem. 2011;58(5):301-310. doi:10.1002/bab.49.

136. AperT, Schmidt A, Duchrow M, Bruch HP. Autologous blood vessels engineered from peripheral blood sample. Eur J Vasc Endovasc Surg. 2007;33(1):33-39. doi:10.1016/j.ejvs.2006.08.008.

137. Neidert MR, Lee ES, Oegema TR, Tranquillo RT. Enhanced fibrin remodeling in vitro with TGF-beta1, insulin and plasmin for improved tissue-equivalents. Biomaterials. 2002;23(17):37173731. doi:10.1016/S0142-9612(02)00106-0.

138. Wechselberger G, Russell RC, Neumeister MW, Schoeller T, PizaKatzer H, Rainer C. Successful transplantation of three tissueengineered cell types using capsule induction technique and fibrin glue as a delivery vehicle. Plast Reconstr Surg. 2002;110(1):123129. doi:10.1097/00006534-200207000-00022. 
139. Willerth SM, Arendas KJ, Gottlieb DI, Sakiyama-Elbert SE. Optimization of fibrin scaffolds for differentiation of murine embryonic stem cells into neural lineage cells. Biomaterials. 2006;27(36):5990-6003. doi:10.1016/j.biomaterials.2006.07.036.

140. Schantz JT, Brandwood A, Hutmacher DW, Khor HL, Bittner K. Osteogenic differentiation of mesenchymal progenitor cells in computer designed fibrin-polymer-ceramic scaffolds manufactured by fused deposition modeling. J Mater Sci Mater Med. 2005;16(9):807-819. doi:10.1007/s10856-005-3584-3.

141. Eyrich D, Brandl F, Appel B, et al. Long-term stable fibrin gels for cartilage engineering. Biomaterials. 2007;28(1):55-65. doi:10.1016/j.biomaterials.2006.08.027.

142. Hunter CJ, Mouw JK, Levenston ME. Dynamic compression of chondrocyte-seeded fibrin gels: effects on matrix accumulation and mechanical stiffness. Osteoarthritis Cartilage. 2004;12(2):117130. doi:10.1016/j.joca.2003.08.009.

143. Perka C, Schultz O, Lindenhayn K, et al. Joint cartilage repair with transplantation of embryonic chondrocytes embedded in collagen-fibrin matrices. Clin Exp Rheumatol. 2000;18(1):13-22.

144. Dohle E, El Bagdadi K, Sader R, Choukroun J, James Kirkpatrick C, Ghanaati S. Platelet-rich fibrin-based matrices to improve angiogenesis in an in vitro co-culture model for bone tissue engineering. J Tissue Eng Regen Med. 2018;12(3):598-610. doi:10.1002/term.2475.

145. Rai B, Teoh SH, Hutmacher DW, Cao T, Ho KH. Novel PCLbased honeycomb scaffolds as drug delivery systems for rhBMP-2. Biomaterials. 2005;26(17):3739-3748. doi:10.1016/j. biomaterials.2004.09.052.

146. Schmoekel H, Schense JC, Weber FE, et al. Bone healing in the rat and dog with nonglycosylated BMP-2 demonstrating low solubility in fibrin matrices. J Orthop Res. 2004;22(2):376-381. doi:10.1016/s0736-0266(03)00188-8.

147. Jeon O, Ryu SH, Chung JH, Kim BS. Control of basic fibroblast growth factor release from fibrin gel with heparin and concentrations of fibrinogen and thrombin. J Control Release. 2005;105(3):249-259. doi:10.1016/j.jconrel.2005.03.023.

148. Taylor SJ, McDonald JW, 3rd, Sakiyama-Elbert SE. Controlled release of neurotrophin-3 from fibrin gels for spinal cord injury. J Control Release. 2004;98(2):281-294. doi:10.1016/j. jconrel.2004.05.003.

149. Lee AC, Yu VM, Lowe JB, 3rd, et al. Controlled release of nerve growth factor enhances sciatic nerve regeneration. Exp Neurol. 2003;184(1):295-303. doi:10.1016/S0014-4886(03)00258-9.

150. Ameer GA, Mahmood TA, Langer R. A biodegradable composite scaffold for cell transplantation. J Orthop Res. 2002;20(1):16-19. doi:10.1016/s0736-0266(01)00074-2.

151. Perka C, Spitzer RS, Lindenhayn K, Sittinger M, Schultz O. Matrix-mixed culture: new methodology for chondrocyte culture and preparation of cartilage transplants. J Biomed Mater Res. 2000;49(3):305-311. doi:10.1002/(SICI)10974636(20000305)49:33.0.CO;2-9.

152. Rowe SL, Lee S, Stegemann JP. Influence of thrombin concentration on the mechanical and morphological properties of cell-seeded fibrin hydrogels. Acta Biomater. 2007;3(1):59-67. doi:10.1016/j. actbio.2006.08.006.

153. Mol A, van Lieshout MI, Dam-de Veen CG, et al. Fibrin as a cell carrier in cardiovascular tissue engineering applications. Biomaterials. 2005;26(16):3113-3121. doi:10.1016/j. biomaterials.2004.08.007.

154. Zhou $\mathrm{H}, \mathrm{Xu} \mathrm{HH}$. The fast release of stem cells from alginate-fibrin microbeads in injectable scaffolds for bone tissue engineering. Biomaterials. 2011;32(30):7503-7513. doi:10.1016/j. biomaterials.2011.06.045
155. Chekanov V, Akhtar M, Tchekanov G, et al. Transplantation of autologous endothelial cells induces angiogenesis. Pacing Clin Electrophysiol. 2003;26(1 Pt 2):496-499. doi:10.1046/j.14609592.2003.00080.x.

156. Christman KL, Vardanian AJ, Fang Q, Sievers RE, Fok HH, Lee RJ. Injectable fibrin scaffold improves cell transplant survival, reduces infarct expansion, and induces neovasculature formation in ischemic myocardium. J Am Coll Cardiol. 2004;44(3):654-660. doi:10.1016/j.jacc.2004.04.040.

157. Birla RK, Borschel GH, Dennis RG, Brown DL. Myocardial engineering in vivo: formation and characterization of contractile, vascularized three-dimensional cardiac tissue. Tissue Eng. 2005;11(5-6):803-813. doi:10.1089/ten.2005.11.803.

158. Ryu JH, Kim IK, Cho SW, et al. Implantation of bone marrow mononuclear cells using injectable fibrin matrix enhances neovascularization in infarcted myocardium. Biomaterials. 2005;26(3):319-326. doi:10.1016/j.biomaterials.2004.02.058.

159. Flanagan TC, Cornelissen C, Koch S, et al. The in vitro development of autologous fibrin-based tissue-engineered heart valves through optimised dynamic conditioning. Biomaterials. 2007;28(23):33883397.doi:10.1016/j.biomaterials.2007.04.012.

160. Terrovitis J, Lautamaki R, Bonios $M$, et al. Noninvasive quantification and optimization of acute cell retention by in vivo positron emission tomography after intramyocardial cardiacderived stem cell delivery. J Am Coll Cardiol. 2009;54(17):16191626. doi:10.1016/j.jacc.2009.04.097.

161. Zhang X, Wang H, Ma X, et al. Preservation of the cardiac function in infarcted rat hearts by the transplantation of adipose-derived stem cells with injectable fibrin scaffolds. Exp Biol Med (Maywood). 2010;235(12):1505-1515. doi:10.1258/ebm.2010.010175.

162. Martens TP, Godier AF, Parks JJ, et al. Percutaneous cell delivery into the heart using hydrogels polymerizing in situ. Cell Transplant. 2009;18(3):297-304. doi:10.3727/096368909788534915.

163. Johnson PJ, Parker SR, Sakiyama-Elbert SE. Fibrin-based tissue engineering scaffolds enhance neural fiber sprouting and delay the accumulation of reactive astrocytes at the lesion in a subacute model of spinal cord injury. J Biomed Mater Res A. 2010;92(1):152163. doi:10.1002/jbm.a.32343.

164. Almeida HV, Eswaramoorthy R, Cunniffe GM, Buckley CT, O'Brien FJ, Kelly DJ. Fibrin hydrogels functionalized with cartilage extracellular matrix and incorporating freshly isolated stromal cells as an injectable for cartilage regeneration. Acta Biomater. 2016;36:55-62. doi:10.1016/j.actbio.2016.03.008.

165. Singaravelu S, Ramanathan G, Raja MD, et al. Biomimetic interconnected porous keratin-fibrin-gelatin 3D sponge for tissue engineering application. Int J Biol Macromol. 2016;86:810-819. doi:10.1016/j.ijbiomac.2016.02.021.

166. Sell SA, Wolfe PS, Garg K, McCool JM, Rodriguez IA, Bowlin GL. The use of natural polymers in tissue engineering: a focus on electrospun extracellular matrix analogues. Polymers. 2010;2(4):522-553. doi:10.3390/polym2040522.

167. Rouwkema J, Khademhosseini A. Vascularization and Angiogenesis in Tissue Engineering: Beyond Creating Static Networks. Trends Biotechnol. 2016;34(9):733-745. doi:10.1016/j. tibtech.2016.03.002.

168. Koffler J, Kaufman-Francis K, Shandalov Y, et al. Improved vascular organization enhances functional integration of engineered skeletal muscle grafts. Proc Natl Acad Sci U S A. 2011;108(36):1478914794. doi:10.1073/pnas.1017825108.

169. Patterson J, Martino MM, Hubbell JA. Biomimetic materials in tissue engineering. Mater Today. 2010;13(1-2):14-22. doi:10.1016/ S1369-7021(10)70013-4. 